\title{
In search of an EU approach to headscarf bans: where to go after Achbita and Bougnaoui?
}

\author{
Titia Loenen* \\ Professor of Human Rights and Diversity at Leiden University
}

\begin{abstract}
The wearing of a headscarf at work is a contested issue in many European countries and the legal approach towards headscarf bans varies greatly. So far, the European Court of Human Rights seems to have given its blessing to widely diverging approaches by granting the national authorities a wide margin of appreciation in regulating this matter. More recently the Court of Justice of the $E U$ was also confronted with this issue in the cases Achbita and Bougnaoui. However, the resulting preliminary rulings are formulated in such a terse and minimally motivated way as to generate confusion rather than provide clear guidance to the member states. This contribution seeks to explore the space left by the two judgments for further interpretation of the relevant EU standards and to discuss the different ways in which the CJEU could proceed in future cases, taking also into account the case law of the Strasbourg Court and the diverging approaches in the member states.
\end{abstract}

\section{Introduction}

The wearing of a headscarf at work is a contested issue in many European countries and the legal approach towards headscarf bans varies greatly. ${ }^{1}$ In some countries such bans are seen as an unacceptable limitation of the freedom of religion and/or a violation of non-discrimination law; in other countries they are allowed because priority is given to other important interests or values. Where employment in the public sphere is concerned, the principle of state neutrality often plays a crucial role in limiting the freedom of workers. ${ }^{2}$

So far, in its interpretation of the European Convention on Human Rights (ECHR) to which all European countries are bound, the European Court of Human Rights (ECtHR), seems to have given its blessing to both approaches

* DOI 10.7590/187479817X15095380840357 1874-7981 2017 Review of European Administrative Law

1 See for an informative sample of practices in both European and non-European countries D. McGoldrick, Human rights and religion: the Islamic headscarf debate in Europe, Hart Publishing: Oxford/Portland 2006.

2 The United Kingdom and France seem to represent two opposite models in this respect, with the UK providing employees far more liberty to wear religious dress or symbols at work than workers in France, in particular where public sector employment is concerned. Other countries such as Germany and the Netherlands are somewhere in between these two models. See for an overview H. van Ooijen, Religious Symbols in Public Functions: Unveiling State Neutrality. A 
at the same time by granting the national authorities a wide margin of appreciation in regulating this matter.

More recently the Court of Justice of the EU (CJEU) was also confronted with this issue in the cases Achbita and Bougnaoui. ${ }^{3}$ In these cases it was called upon to decide whether EU Directive $2000 / 78$, which prohibits discrimination on grounds of religion in employment, should be interpreted to allow for a headscarf ban in the workplace of a private enterprise. ${ }^{4}$ However, the resulting preliminary rulings are formulated in such a terse and minimally motivated way as to generate confusion rather than provide clear guidance to the member states. In this respect, this contribution takes issue with the first reaction to the judgments in the media, concluding that the CJEU gives employers a more or less free hand to prohibit headscarves in the workplace. ${ }^{5}$ This conclusion is too quick and up for discussion.

Remarkably the core reasoning of each of the rulings does not consist of much more than a single page. This is all the more surprising as the Court could have drawn from two elaborate opinions of the Advocates General Kokott and Sharpston. ${ }^{6}$ This terseness and lack of clarity may very well be explained by a serious and profound disagreement within the Court on the proper interpretation of the applicable EU law regarding this issue. Given the widely diverging opinions of the Advocate Generals in both cases and the equally widely diverging approaches in the member states, this would not be surprising. ${ }^{7}$ In such circumstances minimalism and ambiguity in the judgment provide a way to arrive at some sort of consensus that can be supported by a majority. In addition they provide the opportunity to revisit the issue in future cases - which will no doubt reach the Court - with sufficient flexibility to further develop the case law as the Court sees fit.

If this reading of the judgment is correct it implies two important points. First of all it implies that the outcome of the judgments is to be approached as an intermediate phase, as a first step towards the development of a fuller and clearer interpretative framework for addressing the regulation of religious

Comparative Analysis of Dutch, English and French Justifications for Limiting the Freedom of Public Officials to Display Religious Symbols, Intersentia: Antwerpen 2012.

3 CJEU (Grand Chamber) 14 March 2017, C-157/15 (Achbita v. G4S); CJEU (Grand Chamber) 14 March 2017, C-188/15 (Bougnaoui and ADDH v. Micropole).

4 Directive $2000 / 78 / \mathrm{EC}$ of 27 November 2000 establishing a general framework for equal treatment in employment and occupation, OJ L303/16 (Framework directive).

5 See. e.g. the Guardian, www.theguardian.com/law/2017/mar/14/employers-can-ban-staff-fromwearing-headscarves-european-court-rules; The Telegraph, www.tele-

graph.co.uk/news/2016/05/31/bosses-can-ban-headscarves-and-crucifixes-eu-judge-says/; The NY Times www.nytimes.com/2017/03/14/world/europe/headscarves-ban-european-court.html (last accessed 2 October 2017).

6 Opinion AG Kokott of 31 May 2016 in case C-157/15 (Achbita); Opinion AG Sharpston of 13 July 2016 in case C-188/15 (Bougnaoui).

7 Ibid. 
clothing or symbols in the workplace under EU law rather than providing definite and clear guidance to the member states. Secondly, this reading implies that the judgments probably leave quite some room for further legal development and interpretation of the applicable EU law. As a consequence, it is important to take a closer look at them to analyze this scope for further interpretation under EU law in more detail, also taking into account the case law of the ECtHR and the diverging approaches in the member states.

This contribution seeks to do just that. It will start by briefly discussing the approaches to the wearing of religious dress or symbols in the workplace in three countries that can be seen as representative of the widely diverging views within the EU on this issue: the UK, France and the Netherlands (section 2). As will become clear below, the UK represents one end of the spectrum by taking a very accommodating approach to workers who wish to wear religious dress or symbols, giving priority to their freedom to do so both in the public and the private sector. France is representative of the other side of the spectrum by banning the wearing of all religious dress and symbols from the entire public and related sector. The Netherlands is somewhere in between these two approaches. After exploring the most relevant case law of the ECtHR regarding religious dress and symbols (section 3) this contribution will continue with a detailed analysis of the preliminary rulings of the CJEU in the cases Achbita and Bougnaoui (section 4). Section 5 will discuss the different ways in which the CJEU could proceed in future cases including the main reasons for and against going each of these ways. The final section will draw some overall conclusions.

\section{Diverging approaches to religious dress in the workplace: the UK, France and the Netherlands}

Within Europe widely diverging practices and policies exist regarding the wearing of religious dress or symbols in the workplace. In particular, where employment in the public sphere is at stake the differences stand out; differences regarding the private sector are often less apparent or pronounced. The following overview of legal approaches in France, the UK and the Netherlands regarding wearing religious dress or symbols in public and private employment is very illustrative of European diversity on this matter.

\subsection{Religious dress in the public sector}

In the public sector diverging approaches to the wearing of religious dress or symbols at work are heavily influenced if not determined by diverging conceptions of the principle of state neutrality. To understand why this is the case it is useful to first devote a few words to this principle. 


\subsubsection{State neutrality}

The notion of state neutrality is part of liberal democracy and has its roots in the liberal notion that every person should be free to decide about what constitutes 'the good life' for himself or herself and to pursue it during his or her lifetime. The state should respect this fundamental liberty and be careful not to impose a particular vision of the good life on its citizens; it should be neutral. Being a major element of people's perception of the good life, state neutrality must include neutrality regarding religion and belief. ${ }^{8}$

Generally speaking state neutrality in respect of religion entails several things. ${ }^{9}$ First of all, state neutrality calls for institutional separation of church and state so as to guarantee their mutual independence. Secondly, state neutrality requires the state not to evaluate, favour or disfavour religions or beliefs, be it in general or in its interaction with individuals and communities. This means the state should not pronounce itself on whether something constitutes a religion or belief and it should not give preferential treatment to one religion over another. Thirdly, the state should not impose religion or belief by either forcing or prohibiting individuals to adhere to a particular religion or by proselytism or indoctrination in favour of a particular religion. Fourthly, state neutrality means that the state should not favour or disfavour individuals or communities on the basis of their religion or belief in their direct contact with these individuals, or put simply, the state should not treat persons differentially on grounds of religion or belief.

Whereas the above features and requirements of the principle of state neutrality seem to be broadly accepted, the way to achieve such state neutrality is not. In fact, in the academic literature two distinct and opposite approaches to achieving state neutrality are distinguished: exclusive and inclusive neutrality. ${ }^{10}$ On the one hand, exclusive neutrality seeks to achieve state neutrality by being 'religion blind', that is by completely ignoring religious identities and differences and by requiring the state not to express any affiliation with religion. As a consequence, religious expressions are to be banned from the public sphere. Inclusive neutrality, on the other hand, seeks to achieve state neutrality by recognition of religious identities and diversity. It takes a different view on what is neutral. Banning religious expressions from the public sphere is perceived as not being neutral because of the negative impact this entails for religious people.

For a fuller discussion see $\mathrm{H}$. van Ooijen, Religious symbols in public functions. A comparative analysis of Dutch, English and French justifications for limiting the freedom of public officials to display religious symbols (dissertation Leiden University, Antwerpen: Intersentia, 2012).

9 The following overview is also based on Van Ooijen, supra note 8, Chapter 4.

10 The terminology seems to have been coined by W. van den Burg, but the models they represent are common throughout the literature on state neutrality. W. van der Burg, Inclusive Neutrality in the Classroom, Yearbook of the European Association for Education Law and Policy, 2011. Available at SSRN: https://ssrn.com/abstract=1907594. 
The implication here being that religious expressions in the public sphere should be allowed. A crucial condition for the state still being regarded as neutral then turns on equality and equal treatment: all religions should be equally allowed to be visible and present. The state cannot be selective. So in fact neutrality is achieved through inclusion and accommodation of all religions in the public sphere on an equal basis.

To conclude, state neutrality is not a straightforward notion at all. This can be illustrated by the diverging approaches to the wearing of religious dress or symbols in France, the UK and the Netherlands.

\subsubsection{France, the UK and the Netherlands}

France generally adheres to a very specific, strict and 'exclusive' conception of state neutrality which is encapsulated in the principle of laïcité. ${ }^{11}$ This principle requires all public servants in whatever function or job to abstain from donning any religious dress or symbols in the workplace. ${ }^{12}$ Religious expressions are deemed to belong to the private sphere and are to be excluded from the state sphere. Public servants are seen as representatives of the state and as such should always appear to be strictly neutral and leave their religious identity behind when at work.

This very strict version of state neutrality is perceived as a cornerstone of the French state. It is closely connected to both the institutional separation of Church and State and the French republican ideal of citizenship. The French approach combines full recognition of the freedom to express religious personal identity and diversity in the private sphere with a requirement of equal and neutral citizenship in the state sphere. Because neutral citizenship is all important, neutrality in public education is also of central concern as it plays a crucial role in developing this citizenship ideal across the nation.

The strictness of the French approach is borne out by the fact that the ban on religious dress or symbols applies irrespective of the public official concerned being in visible contact with the general public. Also illustrative is the inclusion of pupils in the public school system: pupils in primary and secondary education

$11 \quad$ For an elaboration of the concept of laïcité and its consequences as described in this brief overview see the report by the Commission that advised the French Government on the introduction of a ban on religious symbols in public education, Commission de réflexion sur l'application du principe de laïcité dans la République, Rapport au président de la République et au parlement, 11 décembre 2003, www.ladocumentationfrancaise.fr/rapports-publics/044000099rapport-2003-au-president-de-la-republique-et-au-parlement (last accessed 29 September 2017).

12 It covers people working in core state functions such as the judiciary and the police, but also public school teachers, administrative personnel at ministries or other public institutions and cleaning personnel employed by the state. 
are equally subject to the rules as teachers. ${ }^{13}$ Last but not least the laïcité principle is also applicable to private companies providing public services, thus extending the prohibition to wear religious dress or symbols at work far beyond strictly public employment relationships.

The approach in the UK lies on the other end of the scale. The UK clearly adheres to an inclusive model of state neutrality by putting the freedom of public officials to express their religion first. ${ }^{14}$ Almost no restrictions on the wearing of religious dress or symbols are deemed acceptable. Exceptions primarily regard functional justifications for restrictions. Thus, for example, the wearing of face covering veils may be prohibited for reasons of communication. ${ }^{15}$ In this respect it is important to note that not just ordinary public servants or public school teachers are allowed to wear a headscarf or turban at work, but also police officers and judges. In fact, 2003 saw the first Sikh judge sitting on the High Court, turban and all. ${ }^{16}$ All this is not to say no public debate exists on such issues, but overall the legal approach is very accommodationist. ${ }^{17}$

The Dutch approach is somewhere in between France and the UK. It follows primarily an inclusionary model, but not all over the board. ${ }^{18}$ For the far majority of public servants, including public school teachers, Dutch practice is similar to the UK. They are free to wear a headscarf or other religious dress or symbols at work. Exceptions to this freedom can only be based on functional requirements such as safety, hygiene or communication. The latter is also considered to provide a justification for banning face covering veils. ${ }^{19}$

13 In response to diverging practices in French schools a legal ban on the wearing of religious symbols in primary and secondary public schools was adopted in 2004, Loi $n^{\circ} 2004-228 d u$ 15 mars 2004 encadrant, en application du principe de laïcité, le port de signes ou de tenues manifestant une appartenance religieuse dans les écoles, collèges et lycées publics. www.legifrance.gouv.fr/affichTexte.do?cidTexte=JORFTEXToo०o००417977\&categorieLien=id (last accessed 29 September 2017).

14 An anomaly to state neutrality in the UK being the still privileged position of the Anglican church in the institutional arrangements. In practice, however, this position should not be overestimated as the UK has considerably moved towards becoming a secular state in practice. See P.W. Edge, Secularism and establishment in the United Kingdom, in: P. Cumper and T. Lewis (eds), Religion, rights and secular society. European perspectives, Elgar: Cheltenham 2012, p. 38-57.

15 See Employment Appeal tribunal 30 March 2007, Azmi v. Kirklees Metropolitan Borough Council, [2007] I.C.R. 1154. In this case a primary school teacher was dismissed because her niqab interfered with proper communication with her pupils. Her appeal against this dismissal was dismissed by the Employment Appeal Tribunal.

16 See 'High court judge will be first to wear turban', www.guardian.co.uk/uk/2003/mar/24/race.world (last accessed 29 September 2017).

17 See for some of the discussions McGoldrick, The headscarf debate in Europe, supra note 1, Chapter 6.

18 See for a fuller picture M. van den Brink and T. Loenen, The Netherlands: neutral but not indifferent, in P. Cumper and T. Lewis (eds), Religion, rights and secular society. European perspectives, Elgar: Cheltenham 2012, p. 17-37.

19 In fact a formal legal prohibition of face covering clothing in education, public transport, public buildings and healthcare is pending with the Senate, see Wetsvoorstel gedeeltelijk verbod gezichtsbedekkende kleding (Kamerstukken II, 2015-2016, no. 34 349), https://zoek.officielebekendmakingen.nl/dossier/34349. 
For a few distinct categories of public officials, the policy is more in line with the French approach. These categories concern public servants who are involved in core state functions. Thus for the judiciary strict rules apply which do not allow for the wearing of any religious attire in the court room. ${ }^{20}$ The same applies to other expressions of personal belief or identity, such as, for instance, a pink triangle or political symbols. As such, the policy is not singling out religious expressions, but seeks to achieve a more overall outwardly neutral appearance.

For the police similar restrictions apply, though the policy regarding this category of public servants is not firmly settled it seems. Some twenty years ago plans were developed to design matching headscarves with police uniforms, but before this was realized the mood changed and after quite some debates the police settled for a more restrictive policy of 'life style neutrality'. ${ }^{21}$ This policy does not allow for the wearing of religious dress or symbols during work and more generally prohibits visible expressions of religious, political and personal convictions or identity, including conspicuous tattoos, haircuts and piercings. The Dutch national institute for human rights, the College voor de Rechten van de Mens, issued a critical advice regarding the policy because of its potentially discriminatory impact on specific religious groups such as Muslim women. The College in particular takes issue with the policy being applicable to all police personnel without distinguishing between those who are in touch with the general public and those who are not. ${ }^{22}$ In May 2017 a proposal by the head of police in Amsterdam to change this policy and allow Muslim police officers to wear a headscarf while on duty met with fierce reactions on social media, showing the continuing controversy surrounding this issue. The national head of police subsequently decided not to pursue this idea any further. ${ }^{23}$

This brief sample of approaches to the wearing of religious dress or symbols in public functions shows how widely different approaches exist across European countries, reflecting diverging conceptions of state neutrality as either exclusive or inclusive neutrality.

20 This prohibition is not based on a specific legislative provision, but on the application of the dress codes formulated for the judiciary.

${ }^{21}$ For a discussion of the backgrounds to this change see S. Saharso and D. Lettinga, 'Contentious Citizenship: Policies and Debates on theVeil in the Netherlands', Social Politics, vol. 15, 2009, p. $455-480$.

22 Advies 2007/08 inzake uiterlijke verschijningsvormen politie 'Pluriform uniform?' (Advice 2007/08 concerning outward appearance of the police 'pluriform uniform?'). Available on the CRM website, www.mensenrechten.nl/publicaties/zoek.

23 www.volkskrant.nl/binnenland/hoofddoek-blijft-verboden-bij-politie-duidelijk-geen-draagvlakvoor-dit-idee a4497127/ (last accessed 2 October 2017). 


\subsection{Religious dress in the private sector}

As far as private sector employment is concerned differences between the three countries are less stark. Approaches in the UK and the Netherlands are quite similar indeed. The freedom of workers to wear religious dress or symbols is the default position. Any limitations have to be justified and are only acceptable when functionally necessary, that is for reasons of safety, hygiene or other functional reasons. ${ }^{24}$

The situation in France is less clear and does not seem to be fully crystallized, but nevertheless the approach to wearing religious clothing or other symbols is definitely not as strict as in the public sector; the private sector not being ruled by the constitutional value of laïcité. As it is put explicitly in the ministerial guide on religious matters in employment, the State is 'laïque'; whereas the civil society is governed by the freedom of religion and private enterprises and not under an obligation of neutrality. ${ }^{25}$ Accordingly, also in France and in the private sector a prohibition of wearing a headscarf or other religious clothing or symbol requires a functional justification and must be proportionate to the aim pursued. ${ }^{26}$ In its application, however, justifications are more easily accepted than in the UK or the Netherlands, as can be illustrated by the Baby-Loup case. ${ }^{27}$ In this case the French Court of Cassation held that a day care center could require an employee to refrain from wearing a headscarf because of its policy of neutrality towards children and parents. Interestingly this ruling was rendered by the plenary Court, overruling a decision by its Social Chamber in favour of the employee. ${ }^{28}$ If anything, this shows that the acceptability of a neutrality policy by a private employer is indeed not self-evident. The ministerial guide concerning religious matters in employment also points this out. It provides a lot of examples of decisions handed down by the courts regarding headscarves

24 I leave aside here the position of religious institutions - for example the Catholic or Anglican Church - as well as other organizations based on a religious ethos, such as denominational schools or the Salvation Army. Such organisations can claim exceptions to this strict approach to protect their specific identity as is provided for in article $4(2)$ of Directive $2000 / 78$.

25 '...c'est la République c'est à dire l'État, qui est laïque, tandis que la société civile reste gouvernée par la liberté de religion' and '...l'entreprise privée n'est pas tenue à une obligation de neutralité'. See Ministère du Travail, de l'Emploi, de la Formation professionelle et du Dialogue Social, Guide pratique du fait religieux dans les entreprises privees, Janvier 2017, http://travail-emploi.gouv.fr/IMG/pdf/guide_employeurs_valide.pdf (last accessed 22 September 2017). Ibid., p. 7-8.

27 Cour de cassation - Assemblée Plénière, Arrêt n 612 du 25 juin 2014 (13-28.369); ECLI:FR:CCASS:2014:APoo612.

28 For an overview of the various proceedings in the case see F. Johannès, Baby Loup: épilogue et décision de la Cour de cassation, 27 June 2014,

http://libertes.blog.lemonde.fr/2014/o6/27/baby-loup-epilogue-et-decision-de-la-cour-de-cassation/ (last accessed 1 October 2017). 
and other religious expressions in employment and points out that the jurisprudence is not yet fully set. ${ }^{29}$

However diverging the above practices are, so far the European Court of Human Rights seems to consider all of them compatible with the rights enshrined in the ECHR as can be inferred from the following overview of its case law.

\section{The case law of the Strasbourg Court on religious dress in the workplace}

\subsection{Religious dress in the public sector}

The case law of the ECtHR so far largely concerns religious dress or symbols in the public sphere. The Court's line of jurisprudence started with Dahlab v. Switzerland. ${ }^{30}$ Though this was an admissibility decision, it set the stage by accepting the argument of state neutrality as justification for the dismissal of a public school teacher who started to wear a headscarf in the class room. In subsequent cases the Court elaborated its approach and held time and again that the states parties to the Convention enjoy a wide margin of appreciation in regulating this type of issue. Several landmark cases merit attention in this respect.

The first Grand Chamber judgment on the regulation of religious clothing and symbols in the public sphere was rendered in the case of Sahin v. Turkey. ${ }^{11}$ It concerned a complaint by a student at a Turkish state university regarding a ban on wearing religious dress or symbols, which was applicable to both personnel and pupils. The main argument for the ban was the principle of state neutrality that has its roots in the foundation of the Turkish Republic and is constitutionally guaranteed. The Court upheld the Turkish ban and considered that it did not violate the freedom of religion as enshrined in the ECHR. In its reasoning the Court gave pride of place to the margin of appreciation to be left to the national authorities in this matter. It emphasized that 'where questions concerning the relationship between State and religions are concerned, on which opinion in a democratic society may reasonably differ widely, the role of the national decision-making body must be given special importance'. ${ }^{32}$ As a consequence it left a wide margin of appreciation to the Turkish authorities to

\footnotetext{
29 Guide pratique du fait religieux dans les entreprises privees, supra note 25, p. 15.

30 ECtHR 15 February 2001, Dahlab v. Switzerland (decision on admissibility), appl.nr. 42393/98.

31 ECtHR 10 November 2005 (Grand Chamber), Sahin v. Turkey, appl.no. 44774/98.

32 Sahin, supra note 31, para. 109.
} 
decide whether it is indeed 'necessary' to ban the wearing of all religious clothing and symbols in public education. The Court then accepted the arguments put forward by the Turkish Government, in particular those referring to the specific constitutional value attached to the principle of state neutrality and the strong political significance attached to the wearing of a headscarf within the context of the growing influence of extremist political movements in the country. According to dissenting judge Tulkens, the margin of appreciation awarded to the state in this case is so wide as to make her conclude that 'European supervision seems quite simply to be absent from the judgment'. ${ }^{33}$

In the meantime, after widely publicized debates on the issue, France had adopted legislation prohibiting the wearing of religious dress and symbols throughout primary and secondary public education in $2004 \cdot{ }^{34}$ Given the controversies surrounding this ban, a complaint by affected pupils was bound to reach the Strasbourg Court sooner or later. An important question the Court would have to answer concerned the different contexts of the ban, which in France mainly affects minority religions. Would this difference in context lead to a different outcome if compared to the Sahin judgment? In 2009 the Court had the opportunity to rule on this issue in response to complaints by both Muslim and Sikh pupils. ${ }^{35}$ Again the Court accepted the argument of state neutrality without much further scrutiny by reiterating the wide margin of appreciation the national authorities enjoy in regulating such issues. It held the complaints to be manifestly ill-founded and thus inadmissible. ${ }^{36}$

Another Grand Chamber judgment worth mentioning is Lautsi v. Italy even if it is not about the freedom of an individual person to express his or her religion through dress or symbols in view of the principle of state neutrality, but rather about the freedom of the state to hang crucifixes in the public school classroom in relation to that principle. It is nevertheless an important case for the topic of this contribution as the Court reaffirms it will take a very deferential approach

33 Sahin supra note 31, dissenting opinion Tulkens. The wide margin of appreciation is also pointed out in academic comments on the case, see .e.g. T. Lewis, What not to wear: religious rights, the European Court and the margin of appreciation, International and Comparative Law Quarterly vol. 56, 2007, p. 395-414.

34 Loi $\mathrm{n}^{\circ}$ 2004-228, supra note 12. For the background and developments leading up to this ban see McGoldrick, supra note 1, Chapter 2: The Islamic headscarf debate in France.

35 The cases were all decided on the same day, ECrtHR 30 June 2009; on Muslim women's complaints: Aktas v. France, appl. no. 43563/o8; Bayrakv. France, appl.no. 14308/o8; Gamaleddyn v. France, appl.no. 18527/08; Ghazal v. France, appl.no. 29134/08; on complaints by Sikh pupils: Javir Singh v. France, appl.no. 25463/o8; Ranjit Singh v. France, appl.no. 27561/o8.

${ }_{36}$ Interestingly the Human Rights Committee, the supervisory body to the International Covenant on Civil and Political Rights came to a different outcome in a similar case, see HRC 1 November 2012, Bikramjit Singh v. France, comm.no. 1852/2008; CCPR/C/106/D/1852/2008. Article 18 ICCPR, which protects the freedom of religion, is very similar to art. $9 \mathrm{ECH}$ in its wording, but contrary to the ECtHR the HRC is more strict in its assessment of the proportionality of the measure. To sacrifice the pupil's rights is not considered necessary and in fact disproportionate (para. 8.7). 
to how national authorities regulate religious dress or symbols in the public sphere more generally.

Interestingly, in the initial Chamber judgment the Court unanimously concluded that the Italian practice constituted an infringement of the Convention. ${ }^{37}$ It held that the State must refrain from imposing beliefs, even indirectly, in places where persons are dependent on it or in places where they are particularly vulnerable, as in school. The State has a duty to uphold confessional neutrality in public education. The Chamber judgment did not accept the Italian argument that hanging a crucifix in the class room should be seen primarily as a historical tradition rather than as a sign of preference for a particular religion. According to the judgment, the compulsory and highly visible presence of crucifixes in classrooms is capable of conflicting with the convictions of pupils of non-Christian religions or those who profess no religion and can be emotionally disturbing for them.

After referral to the Grand Chamber, however, the Court came to the opposite conclusion by holding that Italy did not violate the ECHR. ${ }^{38}$ Though the Court acknowledges that a crucifix is primarily a religious symbol, it does not consider it unacceptable for Italy to have crucifixes present in every public school classroom. Once more the wide margin of appreciation that must be left to the state is determinate. As long as its practice does not amount to indoctrination, the state does not overstep this margin of appreciation. As the Court puts it: 'The State is forbidden to pursue an aim of indoctrination that might be considered as not respecting parents' religious and philosophical convictions. That is the limit that the States must not exceed.... ${ }^{39}$ According to the Court indoctrination is not at issue here as hanging a crucifix on the wall is mainly a 'passive' symbol that cannot exert so much influence as to amount to indoctrination.

Both the Chamber and Grand Chamber judgments were highly publicized and hotly debated in the media. The different outcome of the two judgments is striking, especially in view of the fact that the Chamber judgment was unanimous and the Grand Chamber ruling almost unanimous. In academia the shift to a much more deferential position by the Court is often explained by reference to the sensitivity of the topic and the political context prevalent at the time, characterized by increasing discussions on the position of the court and by challenges to its authority to 'tell states what to do'.40

Whatever the case may be, the Lautsi judgment definitely sets a wide margin of appreciation for states to regulate this type of issue, showing the Court is

\footnotetext{
37 ECtHR 3 November 2009 (Second Section), Lautsi v. Italy, appl.no. 30814/o6.

38 ECtHR 18 March 2011 (Grand Chamber), Lautsi v. Italy, appl.no. 30814/o6.

39 Ibid., para. 62.

40 See for some of these reactions the ECHRBlog, http://echrblog.blogspot.nl/2011/o3/grandchamber-judgment-in-lautsi-no.html (last accessed 30 September 2017).
} 
very hesitant to interfere in this controversial matter. It is important to note that the wide margin of appreciation allows for diverging approaches: both a strict neutrality approach and showing state affiliation with a particular religion are acceptable under the ECHR, as long as the latter does not result in proselytizing or indoctrination.

The jurisprudential lines set out in Sahin and in Lautsi were confirmed in two other cases that are relevant to discuss briefly here. The case of Ebrahimian v. France is of particular relevance because it deals with a civil servant not employed in a core state function. ${ }^{41}$ Ebrahimian was a social worker in a psychiatric public hospital. Her contract was not renewed because she refused to remove her headscarf at work. The Court held that France's general ban on the wearing of ostentatious religious symbols such as a headscarf is allowed as it seeks to protect the rights of others, that is the freedom of religion of the users of a public service. It accepted the abstract and general character of the French justification for the ban and did not require a more rigid and specific assessment of why the wearing of a headscarf by a social worker in the position of Ebrahimian poses a threat to the freedom of religion of others. ${ }^{42}$ The Court explicitly affirmed that a strict approach to state neutrality as laid down in the French constitution does not violate the ECHR and reiterated that the national authorities enjoy a wide margin of appreciation in this area. ${ }^{43}$

To complete this picture of the most relevant case law of the ECtHR about religious dress in the public sphere the S.A.S. judgment merits attention. ${ }^{44}$ This Grand Chamber judgment dealt with the French legal ban - introduced in 2010 - on the wearing of face covering veils such as a niqab or burqa in the public sphere. According to this general and overall ban it is prohibited for anyone to conceal their face in any public place anywhere in France, including on the public road. In assessing the question whether the ban violates article 9 of the ECHR the Court considered the legitimacy of several goals put forward by the French Government. The Court did not accept the argument of the French Government that the ban serves to uphold human dignity or gender equality. The Court considered that women may well freely choose to wear a face covering veil, as is the case with the complainant. The aim of public safety was accepted as a legitimate goal, but it could not save the ban because the Court considered its overall and general nature a disproportional means to achieve this aim. The goal that ultimately withstood the Court's test is the goal of setting minimum requirements for open and interpersonal relationships which form an indispensable element of community life and for 'living together':

41 ECtHR 26 November 2015, Ebrahimian v. France, appl.no. 6446/11, available in French only.

42 This is in fact part of the critique of the dissenting judges in the case, see ibid.

43 Ebrahimian, supra note 41, para. 65-67; Referring to its judgment in Sahin, supra note 31. The Court speaks of 'une ample marge d'appreciation' (para. 65).

44 ECtHR (Grand Chamber) 1 July 2014, S.A.S v. France, appl.no. 43835/11. 
'The Court is therefore able to accept that the barrier raised against others by a veil concealing the face is perceived by the respondent State as breaching the right of others to live in a space of socialization which makes living together easier. $^{\prime 45}$

When answering the question whether a ban stretching as far as all public places is proportionate to achieve this legitimate aim the Court again refers to the wide margin of appreciation states enjoy regarding this subject matter and the need to respect the democratic process that led to the ban. It concludes that 'having regard in particular to the breadth of the margin of appreciation afforded to the respondent State in the present case, the Court finds that the ban imposed by the Law of 11 October 2010 can be regarded as proportionate'. ${ }^{46}$

\subsection{Religious dress in the private sector}

Whereas the case law of the Court on regulating religious dress or symbols in the public sphere is quite extensive as the above overview shows, very limited case law is available addressing the private sector. The landmark case here is Eweida and others v. UK, dating from $2013 .{ }^{47}$ The judgment covers four joined cases, but for the purposes of this contribution the one of main interest is the case of Eweida as it concerns a private company dress code. In this case, the Court also leaves a wide margin of appreciation to the national authorities to regulate this matter. Being the type of case most comparable to the cases dealt with by the CJEU so far, the Eweida judgment merits some more detailed attention before we turn to the Luxembourg rulings.

Ms. Eweida worked as a stewardess with British Airways (BA). She was suspended from her job after she refused to refrain from wearing a small cross expressing her religious conviction on top of her uniform. The wearing of the cross was against the dress code. Though the dress code allowed for the wearing of religious clothing or symbols such as a headscarf or turban, it did not allow for religious symbols that could be hidden and worn below the uniform. After a period of consultation and substantial debate, including in the public media, BA adjusted its policy. Eweida was reinstated in her former job and allowed to visibly wear her cross on top of her uniform. However, as she did not receive compensation for the salary she lost during the suspension period she brought a claim against this decision under national legislation prohibiting discrimina-

45 Ibid., para. 122.

46 Ibid., para. 157. A similar Belgium ban on face covering attire was also upheld more recently referring to the S.A.S judgment and following similar reasoning, see ECtHR 11 July 2017, Belkacemi and Oussar v. Belgium (appl.no. 37798/13) and Dakir v. Belgium (appl.no. 4619/12) .

47 ECtHR 15 January 2013, Eweida a.o v. UK (appl.no. 48420/10, 59842/10, 51671/10 and 36516/10). 
tion on grounds of religion in employment. ${ }^{48}$ When this claim was denied she brought her case to the Strasbourg Court. Interestingly, the non-discrimination legislation on which the national decision was based seeks to implement EU directive $2000 / 78$ covering, among others, discrimination on grounds of religion and belief in employment. It is the same directive being central to the preliminary rulings of the CJEU to be explored below. ${ }^{49}$

In Strasbourg Eweida claims that the outcome of the procedure violates article 9 ECHR. As the case regards at bottom a horizontal relationship and the State is only indirectly engaged, the Court's assessment focuses on the positive obligations of the state to protect Eweida's freedom of religion. The applicable principles, however, are quite comparable, as 'ii]n both contexts regard must be had in particular to the fair balance that has to be struck between the competing interests of the individual and of the community as a whole, subject in any event to the margin of appreciation enjoyed by the State..$^{50}$

First of all, the Court accepts that national anti-discrimination law can also provide a proper way of protecting the freedom of religion as it provides for a thorough assessment of Eweida's claim...$^{51}$ Nevertheless, when assessing whether a fair balance has been struck between the competing interests of Eweida and her employer the Court concludes this has not been the case. Two elements in this assessment merit particular attention. Firstly, the Court in very general terms considers the wish of the employer to project 'a certain corporate image' as 'undoubtedly legitimate' without further reflection on the question whether this would indeed hold for any corporate image..$^{52}$

Secondly, the Court's reasons for concluding that the employer's interests in this respect have been given too much weight are interesting. The Court points to the discrete character of the cross worn by Eweida, which as such 'cannot have detracted from her professional appearance. ${ }^{53}$ The Court adds there is no evidence that wearing other religious dress or symbols by other employees which were allowed under the dress code, such as headscarves, turbans and hijabs, has had any negative impact on the corporate image of BA. ${ }^{54} A$ contrario this reasoning could suggest that the balance could be tipped if particular religious attire is more conspicuous or if it indeed negatively affects the image of the company. A final reason the Court mentions refers to the ad-

See for a brief overview Eweida, supra note 47, para. 9-17.

Council Directive 2000/78/EC of 27 November 2000 establishing a general framework for equal treatment in employment and occupation (Framework directive); see Eweida, supra note 47, para. 43 .

Eweida, supra note 47, para. 84 .

Eweida, supra note 47, para. 92.

Eweida, supra note 47, para. 94.

Eweida, supra note 47, para. 94.

Eweida, supra note 47, para. 94. 
justment of the dress code to allow for the wearing of a visible cross, which shows 'that the earlier prohibition was not of crucial importance'. 55

An important question seems to be whether the Court leaves states in the private sphere a similarly wide margin of appreciation to balance the rights and freedoms at stake as in the public sphere. Though the outcome of its judgment in Eweida would seem to suggest the margin is narrower where the private sector is concerned, I would say that the specific and rather a-typical facts of the case do not warrant such a conclusion. ${ }^{56}$ Indeed, the fact that BA at first allowed turbans and headscarves with the uniform, yet did not allow for a cross to be visibly worn, does not make much sense from the perspective of simple consistency. By not condoning arbitrariness of this kind the Court does not show it departs from the wide margin of appreciation it grants states in regulating manifestations of religion.

All in all, the picture appearing from the case law above shows how a wide margin of appreciation is central to the Court's approach to limitations on the wearing of religious clothing or symbols. It also shows that in this area so far the Court gives its blessing to widely diverging levels of fundamental rights protection across Europe. It has not stepped in to provide for a more uniform approach towards the banning of religious dress or symbols in the public or private sphere. By granting the national authorities an almost free hand the Court accepts that freedom of religion means quite a different thing depending on where you live in Europe. The question is whether the CJEU will follow the same path, a question to which I now turn.

\section{The case law of the Luxembourg court on religious dress in the workplace}

4.1. Facts of the cases Achbita and Bougnaoui and the EU legal framework

Achbita was a receptionist working for a private company, $\mathrm{G}_{4} \mathrm{~S}$, which provided reception and other services for customers in both the public and the private sector. After several years she decided to start wearing a headscarf at work for religious reasons. Her employer did not allow this because of the dress code he wished to uphold. To provide a neutral image of the com-

55 Eweida, supra note 47, para. 94.

${ }^{6}$ In this respect I do not agree with Eva Brems, who suggests Achbita should turn to the Strasbourg Court as having regard to the judgment in Eweida she will probably receive a more favourable outcome there. E. Brems, Analysis: European Court of Justice Allows Bans on Religious Dress in the Workplace, 25 March 2017. https://iacl-aidc-blog.org/2017/03/25/analysis-europeancourt-of-justice-allows-bans-on-religious-dress-in-the-workplace/ (last accessed 1 October 2017). 
pany this dress code prohibited employees from wearing visible signs of their political, philosophical or religious beliefs in the workplace. As Achbita persisted in her wish to wear her headscarf at work she was dismissed. In the national proceedings the Belgian Court asked the CJEU to clarify the meaning of Directive $2000 / 78$, in particular whether the prohibition on wearing an Islamic headscarf arising from a general internal company rule such as at issue constitutes direct discrimination on grounds of religion or belief.

The facts in the case Bougnaoui were similar. Bougnaoui was an IT engineer working for a private company, Micropole, which provides services to all sorts of clients. She was also dismissed because she refused to refrain from wearing her headscarf at work when her employer asked her to do so. Contrary to Achbita, however, the reason why her employer did not agree with her wearing a headscarf was somewhat different. When Bougnaoui was hired she was already wearing a headscarf. Her employer did not object to that as such, but had warned her that it would not always be possible to do so if it would pose problems for the customers she had to work for. In fact, her dismissal was triggered when at some point a customer complained about her wearing a headscarf and Micropole asked her to comply with this. In the national proceedings following her dismissal the French court also asked the CJEU to elucidate the interpretation of Directive $2000 / 78$, in particular whether the wish of a customer who objects to having services provided by a worker wearing an Islamic headscarf may be considered a 'genuine and determining occupational requirement' within the meaning of the Directive.

The preliminary rulings of the CJEU in the cases Achbita and Bougnaoui are the first ones concerning discrimination on the grounds of religion in employment. Both cases turn on the interpretation of Directive $2000 / 78 .{ }^{57}$ This directive prohibits both direct and indirect discrimination on grounds of, among others, religion or belief. ${ }^{5}$ In the context of EU law distinguishing between direct and indirect discrimination is highly relevant as the room for justifications regarding the former are much more restricted than regarding the latter. ${ }^{59}$ Direct discrimination is at stake if an unfavourable treatment is directly based on a prohibited ground of discrimination, whereas indirect discrimination may occur

57 The EU Charter of Fundamental Rights does not play any role in the judgments of the CJEU though the Charter also contains provisions regarding freedom of religion (art. 10) and nondiscrimination (art. 21). The legal framework applicable to the cases is determined by the much more detailed elaboration of the legal standards in the Directive.

58 Other grounds covered are disability, sexual orientation, and age. Separate directives exist regarding discrimination on grounds of sex and race or ethnic origin, which have a much wider scope than employment.

59 For an extensive overview of the directives and the case law of the Court of Justice of the EU see E.Ellis \& P. Watson, EU-anti-discrimination Law (2nd edition), Oxford University Press: Oxford 2012. 
if a certain treatment which is on its face neutral has a disparate impact on a group protected by the discrimination ground.

In respect of direct discrimination, the Directive provides for very few exceptions. The most relevant regards the existence of a so called 'genuine and determining occupational requirement', which was central to the preliminary question of the French court in Bougnaoui. ${ }^{60}$ This exception means that a difference of treatment which is based on a characteristic related to religion or belief 'shall not constitute discrimination where, by reason of the nature of the particular occupational activities concerned or of the context in which they are carried out, such a characteristic constitutes a genuine and determining occupational requirement, provided that the objective is legitimate and the requirement is proportionate' (article 4 (1)). The wording of this exception clause closely follows very similar provisions in the directives regarding discrimination on grounds of sex and race. ${ }^{61}$ In the latter context an example of what was envisaged to be covered by this exception concerns the hiring of actors or actresses. Though refusing a black or female candidate for the role of John F. Kennedy constitutes a difference in treatment directly based on race or sex, such differential treatment is justified because specific racial characteristics and a specific sex are essential features of this historical person.

As far as indirect discrimination may be at stake the Directive allows for a general justification clause. Where an apparently neutral provision, criterion or practice would put persons having a particular religion or belief at a particular disadvantage compared with other persons this does not violate the directive if it is objectively justified by a legitimate aim and the means of achieving that aim are appropriate and necessary $(\operatorname{article} 2(2)(b))$. This implies a proportionality test.

\subsection{Direct and indirect discrimination}

A dress code prohibiting wearing religious clothing or symbols may fall under the scope of the concept of either direct or indirect discrimination depending on the way in which it is formulated and embedded. If religious ex-

60 Directive $2000 / 78$ also contains a very broadly formulated possibility for justifying differential treatment on any of the grounds covered in article 2(5): "This Directive shall be without prejudice to measures laid down by national law which, in a democratic society, are necessary for public security, for the maintenance of public order and the prevention of criminal offences, for the protection of health and for the protection of the rights and freedoms of others'. As the CJEU did not address this exception clause at all I will not explore this further here either.

61 Article 14(2) Directive 2006/54/EC of the European Parliament and of the Council of 5 July 2006 on the implementation of the principle of equal opportunities and equal treatment of men and women in matters of employment and occupation (recast), OJ L 204/23; Article 4 Council Directive $2000 / 43 /$ EC of 29 June 2000 on the implementation of equal treatment irrespective of race or ethnic origin in employment and regarding access to and supply of goods and services (Race directive), OJ L 180/22. 
pressions as such are targeted this would come under the notion of direct discrimination, but if the prohibition is part of a more general rule also including the banning of other expressions of personal identity, such as political and philosophical ones, it would come in the purview of indirect discrimination.

The ruling of the CJEU is most clear where it explains how a prohibition instituted by a private employer to wear a headscarf at work which is directly based on religion should be dealt with. ${ }^{62}$ This is the central issue addressed in Bougnaoui, the case in which the ban on the wearing of a headscarf was instituted after a complaint by a customer. The Court concludes that the exception clause regarding the existence of a 'genuine and determining occupational requirement' is not applicable. This provision can only be successfully invoked in very limited circumstances and refers to requirements that are objectively demanded by the nature of the activities concerned or by the context in which these are carried out. Subjective considerations, such as the employer's wish to comply with his customer's preferences, do not meet this standard. ${ }^{63}$ This seems a convincing reasoning, as it appears hard to argue that the wearing of a headscarf interferes with the professional performance of Bougnaoui as an IT-engineer. Nevertheless, while the Court's reasoning ties in with the position taken by AG Sharpston that the derogation laid down in article 4(1) only applies 'in the most limited of circumstances', it differs from AG Kokott, who considered the provision to be applicable by giving a much broader interpretation of the scope of article 4(1). ${ }^{64}$

As a prohibition on wearing religious clothing or symbols will often be embedded in a broader dress code or policy (or can easily be made part of such a broader framework to avoid allegations of direct discrimination on a prohibited ground) the Court's considerations regarding the assessment of indirect discrimination are much more important and relevant than its holdings regarding direct discrimination. This matter was addressed in the case Achbita, in which the internal company rule was directed at prohibiting visible religious as well as political and philosophical expressions to achieve a neutral appearance towards customers. ${ }^{65}$ Given this importance, it is all the more disappointing that the reasoning and conclusions of the CJEU how to assess whether indirect discrimination is at stake are ambiguous and unclear. The lack of clarity regards

62 In neither of the cases does the Court pronounce itself on the question whether direct or indirect discrimination is actually at stake, leaving it to the national court to assess this on the basis of the specific facts of each case.

63 Bougnaoui, supra note 3, para. 40.

64 Opinion Sharpston, supra note 6, para. 101; Opinion Kokott, supra note 6, para. 77-84.

65 This is not to say that the dismissal of Achbita could not be viewed as direct discrimination after all, as the distinction between direct and indirect discrimination is not always as clear as it would seem. See e.g. Saïla Ouald-Chaib and Valeska David, European Court of Justice keeps the door to religious discrimination in the private workplace opened. The European Court of Human Rights could close it, 27 March 2017 https://strasbourgobservers.com/2017/03/27/europeancourt-of-justice-keeps-the-door-to-religious-discrimination-in-the-private-workplace-openedthe-european-court-of-human-rights-could-close-it/\#more-3549. 
both elements of the test to be applied in cases of potential indirect discrimination: whether a legitimate aim is present and whether the means chosen are appropriate and necessary to achieve that aim.

\subsection{Legitimate aim}

The Court accepts the wish of the company $\mathrm{G}_{4} \mathrm{~S}$ to show a religiously, politically and philosophically neutral image towards its customers as a legitimate goal to pursue. The Court points to the freedom to conduct a business, which has been included as a fundamental freedom in article 16 of the Charter of Fundamental Rights. Though this seems a convincing foundation, when taking a closer look this foundation turns out to be rather shaky. To start with, article 16 of the Charter is formulated in a way that is far from absolute. In fact, what is given with one hand seems to be taken back by the other where the recognition of the freedom to conduct a business is conditional on both EU and national law and practices. ${ }^{66}$ This means both EU law and national law can limit the freedom to conduct a business and this is exactly what anti-discrimination law is all about. EU Directive 2000/78 seeks to limit the freedom of employers to conduct their business or organization as they see fit to protect workers against discrimination by their employer.

This being the case, invoking the freedom to conduct a business to justify potential discrimination cannot be determining. Instead of such reasoning the Court should have looked beyond the 'freedom to conduct a business' to identify which interest the employer could put forward to justify its policy of neutrality. In particular where a private business is concerned it does not seem very easy to identify a legitimate interest of the employer. ${ }^{67}$ Contrary to a public sector employer, a private enterprise cannot invoke the principle of state neutrality. Though as has been explained above, it is up for discussion whether this principle is best served by a policy of banning or accommodating religious expressions in the public sphere, there is no doubt that the principle of state neutrality as such constitutes an important constitutional value of liberal democratic states. But what value or interest could legitimately be underlying a private firm's neutral appearance policy? In this respect it is quite telling that

66 Article 16 reads: 'The freedom to conduct a business in accordance with Union law and national laws and practices is recognised'.

67 See for a discussion on this point also the EuropeanLawBlog by G. Davies, Achbita v. G4S: religious equality squeezed between profit and prejudice, 6 April 2017, http://europeanlawblog.eu/2017/04/06/achbita-v-g4s-religious-equality-squeezed-between-profit-and-prejudice/ and M. Bell, Leaving religion at the door? The European Court of Justice and religios symbols in the workplace, Human Rights Law Review 2017, o, p. 1-13. 
France apparently did not support the position of $\mathrm{G}_{4} \mathrm{~S}$ in the case Achbita and considered the dress code banning religious clothing and symbols not justified. ${ }^{68}$

Economic interests would seem to be a more relevant reason for an employer to make his company appear neutral to the outside world. In the current European context characterized by social tensions surrounding Islam it is not unfeasible to imagine that an employer may want to avoid the risk of incurring negative economic consequences from customers who respond negatively to expressions of Islamic belief, as happened in the case of Bouganoui. In its ruling the Court clearly stated that such subjective feelings cannot be a legitimate reason for a headscarf ban. If this is the case more general neutrality policies which pro-actively play into similar attitudes would seem equally unacceptable.

\subsection{Proportionality of the neutrality rules}

The most important part of the CJEU's rulings - which is also the most unclear and ambiguous part - regards the guidance the Court formulates in the context of the proportionality test to help the domestic court apply Directive $2000 / 78$ to the cases at hand at the national level.

The Court does not give a clear answer to the crucial question about how much room EU law leaves to the national authorities to decide for themselves how to regulate the wearing of religious clothing or symbols in employment. Does the Court interpret EU law as requiring uniform standards in this area or does it - in line with the ECtHR - accept the widely diverging practices at the domestic level by granting the national courts ample discretion to decide whether prohibitions on the wearing of religious clothing or symbols are compatible with Directive 2000/78? Or does it perhaps regard some uniformity necessary under EU law, but is it not agreed on the level of protection to be guaranteed in this way? The ruling in Achbita does not give a clear and unambiguous answer to these questions as it can be read in quite different ways.

On the one hand, the Court seems to formulate uniform standards where it points out two concrete conditions that have to be met to make a neutrality rule prohibiting wearing any sign of political, religious or philosophical conviction proportional. Firstly, such a policy needs to be limited to workers who actually interact with customers. ${ }^{69}$ Secondly, the employer should offer the employee a post not involving any visual contact with customers instead of dismissing him or her, if this can be achieved 'taking into account the inherent con-

68 France's position in this respect is mentioned by Kokott in her opinion, see supra note 6, para. 63.

69 Achbita, supra note 3, para. 42 . 
straints to which the undertaking is subject' and without the employer 'being required to take on an additional burden'.70

Both conditions are not very strict. Though the first condition limits the number of employees that will be affected, it still leaves a very large group of workers exposed to the negative effects of a ban on wearing religious clothing or symbols. The second condition seems to have no real bite at all as moving a worker to another job will probably almost always entail some 'additional burden' for the employer. The Court's weak formulation of the obligation of the employer to accommodate the religious needs of his workers is striking if it is compared to the way in which the obligations of an employer to accommodate the needs of disabled workers are formulated. In the latter case the employer is bound to provide reasonable accommodation unless this creates a 'disproportionate burden'. ${ }^{71}$

Apart from these two conditions the Court does not provide the national court with any other guidance how to apply the proportionality test. It remains silent regarding various important if not crucial considerations that were raised in the opinions of the advocates general in the cases of Achbita and Bougnaoui. To give several examples: both Kokott and Sharpston address the question whether more room exists for a difference in treatment on the grounds of religion than for differential treatment on grounds of sex or race, because religion or belief, unlike sex or race, is not an immutable characteristic. Though both have diverging views on this issue, the Court does not pay any attention to it and does not indicate which of the approaches is the proper one under EU law. ${ }^{72}$

Another example regards the potential intersection between discrimination on grounds of religion and on grounds of sex or race/ethnic origin where a prohibition to wear a headscarf is at stake. In the Belgian and French social context persons who are predominantly affected by such a prohibition arguably belong to minority groups of non-western (often North-African) descent and are predominantly female. If such intersection with race/ethnic origin and sex is considered to be present, this may well warrant a very strict test indeed as differences in treatment based on sex or race are very difficult to justify. As Kokott points out, if a ban would also put employees of a particular sex, colour or ethnic background at a particular disadvantage this might indicate that that ban is disproportionate. ${ }^{73}$ Though Kokott concludes such intersection does not

70 Achbita, supra note 3, para. 43. A third condition which the Court formulates I leave aside here as it seems self-evident indeed: the employer's policy must be pursued in a consistent and systematic manner, see CJEU Achbita, supra note 3, para. 40.

71 Article 5 Directive 2000/78; emphasis added.

72 Opinion Kokott, supra note 6, para. 116; Opinion Sharpston, supra note 6, para. 118.

73 Opinion Kokott, supra note 6, para. 121. 
exist - a conclusion that is up for discussion - the Court does not even address this point. ${ }^{74}$

A final example of important issues completely ignored by the Court regards article 4(2) of the Treaty of European Union (TEU). This provision requires the Union to respect the national identity of the member states. Advocate General Kokott emphasizes the importance of this obligation as a guiding principle to assess the legitimacy of a headscarf ban such as at stake in Achbita. According to her it requires that the application of the Directive must not adversely affect that national identity. As such article $4(2)$ is to be taken into account when interpreting the principle of equal treatment and assessing the justification for any differences in treatment. ${ }^{75}$ To her mind article 4(2) TEU would also seem to imply there is no need for a uniform standard across the member states. ${ }^{76}$

Instead of addressing the issues mentioned, in addition to formulating the two conditions the Court gives a very general direction to the national court:

'It is for the referring court, having regard to all the material in the file, to take into account the interests involved in the case and to limit the restrictions on the freedoms concerned to what is strictly necessary'. ${ }^{77}$

This broad and general wording seems to put the two concrete conditions that have to be met to legitimately introduce a head scarf ban in a new perspective. It suggests that, after all, the Court leaves the ultimate balancing of interests at stake to the national courts and requires them to ensure that limitations on the freedoms involved do not go any further than 'strictly necessary'. All this suggests a stricter test than is encapsulated in the two conditions formulated by the Court. If correct, the two conditions should be interpreted as minimum conditions only, that is conditions that have to be met as a minimum if the national court would hold that - everything considered - a headscarf ban would be legitimate. From the perspective of the protection of the individual rights and freedoms of workers one would hope this is the right interpretation of the rulings, but regretfully the Court is not at all clear whether this is indeed what it means to say.

74 For the intersection between race, sex and religion in regulations banning headscarves see e.g. L. Roseberry, Religion, ethnicity and gender in the Danish headscarf debate in: D. Schiek \& V. Chege (eds), European Union non-discrimination law. Comparative perspectives on multidimensional equality law, Routledge-Cavendish: London/New York 2009, p. 329-351; T. Loenen, The headscarf debate: approaching the intersection of sex, religion and race under the ECHR and EC equality law, in: D. Schiek \& V. Chege (eds), European Union non-discrimination law.

Comparative perspectives on multidimensional equality law, Routledge-Cavendish: London/New York 2009, p. 313-328.

Opinion Kokott, supra note 6, para. 125. See for further discussion of art. 4(2) section 5 .

77 Achbita, supra note 3, para. 43. 
To conclude, the rulings allow for quite different interpretations. On the one hand, an interpretation is possible which reads the decisions as allowing a headscarf ban under the condition of being embedded in a more general, consistently applied policy and being limited to employees who are in direct and visible contact with customers. In addition, the condition applies that an employer cannot dismiss a worker for not abiding by the rules if he can transfer the employee to a different position without additional burden. As mentioned in the introduction, this interpretation seems to have been prominent in the first reactions to the rulings in the media. On the other hand, an interpretation is possible which reads the conditions mentioned as minimum requirements only, leaving a fuller and strict assessment of the headscarf ban to the national level.

Whatever the right interpretation, the lack of clarity left by the Court's rulings leave ample room for further elaboration of the legal framework to be applied in future cases that will no doubt reach the Court at some point. Against this setting it is important to discuss which direction the Court could take and which reasons could inform the choices to be made.

\section{Where to go from Achbita and Bougnaoui?}

Reflecting on the way ahead, I would suggest the most important considerations for the Court would regard a) the conformity of its approach with the ECHR, b) the need to strike a balance between uniformity and diversity and c) the ambition to further develop the social and human rights focus of the EU in tandem with its economic goals. ${ }^{78}$

Conformity of the CJEU approach to the issue of wearing religious clothing or symbols at work with the human rights protection offered under the ECHR is a first important consideration. Even if the EU so far has not acceded to the ECHR and is not directly bound by its provisions, the ECHR has been given a priority position in EU law by article 6(3) TEU which provides that fundamental rights as guaranteed by the Convention constitute general principles of Union law. In addition, the EU Charter of Fundamental Rights gives a priority status to the ECHR where it provides that the meaning and scope of rights corresponding with rights in the ECHR 'shall be the same' as those in the latter Convention. ${ }^{79}$

78 For some additional considerations see M.L.P. Loenen \& L. Vickers, More is less? Multiple protection of human rights in Europe and the risks of erosion of human rights standards, in: S. Morano-Foadi \& L. Vickers (eds), Fundamental rights in the EU. A matter for two courts, Hart Publishing: Oxford/Portland 2015, p. 159-177.

79 Article 52 (4): 'In so far as this Charter contains rights which correspond to rights guaranteed by the Convention for the Protection of Human Rights and Fundamental Freedoms, the meaning and scope of those rights shall be the same as those laid down by the said Convention. This provision shall not prevent Union law providing more extensive protection.' 
As the overview of the case law of the ECtHR in section 3 shows, the national authorities have a wide margin of appreciation to regulate wearing religious clothing and other symbols. There is no doubt this wide margin is applicable in the public sphere and though the case law regarding the private sphere is limited, the Eweida case does not really suggest a different approach as I argued above.

A wide margin of appreciation means that the ECtHR accepts the widely diverging practices existing in European countries, as is exemplified by the approaches in France, the UK and the Netherlands. This being the case, it would seem the EU also has ample room for maneuver in this area, as the broad margin of appreciation would logically also apply to EU standard setting even if the EU as yet is not directly bound by the ECHR. This ample room for setting additional EU standards in this area also fits in with the ECtHR's Bosphorus doctrine. ${ }^{80}$ From the perspective of conformity with the ECHR then, it seems the CJEU could leave the regulation of wearing religious clothing or symbols in employment largely to the national level - just as the ECtHR seems to do or set more uniform standards for the member states.

Perhaps the most important and difficult consideration to inform the CJEU about the direction to take concerns the proper balance to be struck between uniformity and diversity. The particular difficulty here lies in several factors. From a legal perspective, the Court is bound to uphold the efficacy and uniformity of EU law across member states. As far as EU non-discrimination law is concerned, its effectiveness would be greatly hampered if the CJEU allows the transposition of the EU equality directives to result in different standards of protection against discrimination on grounds of religion in different member states.

At the same, and as emphasised by advocate general Kokott, the CJEU is under an obligation to respect the national identity of the member states as guaranteed in article $4(2)$ of the TEU:

'The Union shall respect the equality of Member States before the Treaties as well as their national identities, inherent in their fundamental structures, political and constitutional, inclusive of regional and local self-government.'

80 In the Bosphorus case the ECtHR clarified how to understand the relationship between the ECHR, EU law and the responsibilities of the States Parties in respect of both. The Court starts from the presumption that the protection offered by the EU is 'equivalent' to the protection offered by the ECHR and that no conflict with the Convention exists unless 'in the circumstances of a particular case, it is considered that the protection of the Convention rights was manifestly deficient'. ECtHR 30 June 2005, Bosphorus v. Ireland, appl.no. 45036/98, section 156. More recently the doctrine has been elaborated further in the grand Chamber judgment ECtHR 23 May 2016, Avotinš̌ v. Latvia, appl.no. 17502/07. See for a discussion of this S. Johansen, 'EU law and the ECHR: the Bosphorus presumption is still alive and kicking - the case of Avotins v. Latvia', 24 May 2016, http://eulawanalysis.blogspot.nl/2016/05/eu-law-and-echr-bosphoruspresumption.html (last accessed 2 November). 
There can be little doubt that the relationship between state and religion and the way in which religious manifestations are regulated are closely tied to national history and culture. There can also be hardly any doubt that such arrangements are usually part of states' constitutional structures and can be perceived to belong to national identity as referred to in article 4(2) TEU. The latter may also explain why judgments by international courts regarding this issue are so very sensitive and attract so much media attention. From this perspective it may be wise for the CJEU to leave the regulation of religious clothing and symbols largely to the member states and not to interfere with the decision making in this respect by democratically better placed bodies at the national level.

At the same time, the CJEU may consider it relevant that the lack of common ground across the EU member states regarding the regulation of religious expressions at work is significantly less stark in the private sphere than it is in the public sphere and - if we can take France as a yardstick - not constitutionally embedded. As such it would be rather far-fetched to characterize neutrality policies by employers in the private sector as part of the constitutional traditions of member states. This would suggest that developing more uniform and strict standards regarding private sector employment would not engage article 4(2) TEU.

A third consideration for the CJEU to take into account concerns the EU commitment to improve the protection of fundamental rights across the Union to which the adoption of the Charter of Fundamental Rights as a legally binding part of EU law testifies. Directive 2000/78 is also a clear manifestation of this more social and human rights face of the EU and its ambitions. To live up to this commitment one would expect the CJEU to strive as a matter of general principle for a high level of protection of rights and freedoms of workers, including their religious freedom. Allowing the member states to severely limit this freedom in the workplace does not seem to sit easily with this ambition. At the same time, article $5^{1}$ (3) of the EU Charter of Fundamental Rights expressly provides for the possibility of EU law giving more extensive protection than the ECHR.

In particular, where prohibitions on wearing religious clothing and symbols are at stake, economic and social considerations could be of additional concern. The workers most affected by such prohibitions belong to groups that are most in need of economic and social integration: persons - and in particular women from ethnic minority groups for whom employment is generally perceived as crucial for integration into society. In addition, condoning much lower protection of religious freedom in the workplace in some countries than in others may well negatively affect the free movement of workers within the EU and thus compromise one of the Union's foundational freedoms.

Given the above considerations, a middle ground that the court could take is to set strict and uniform standards in the private sphere and to leave more 
room for diversity in the public sphere. Being strict in the private sector would require the Court to be critical of the reasons that can be put forward by a private employer to prohibit wearing religious clothing or symbols at work, in particular if the goal is formulated as a policy of neutrality. In addition, the Court should then strictly review the proportionality of a ban on wearing of religious clothing or symbols to achieve such neutrality. In both respects the Court could be inspired by the approaches in the UK and in the Netherlands.

Being more lenient and leaving more room for diversity in the public sector would tie in with what are undeniably widely diverging and constitutionally embedded approaches to state neutrality. At the same time, even if the Court leaves much leeway to the member states in the public sphere it could require them to limit the scope of prohibitions to wear religious clothing or symbols to where this is strictly necessary. Thus, for instance, it could also apply the two conditions for a ban on religious clothing or symbols as formulated in Achbita to the public sector. Limiting the applicability of a ban to those in face-to-face contact with the general public and providing for alternative positions for those who cannot abide with the neutrality requirement for religious reasons would significantly reduce the number of people affected by a ban without disrespecting the choice for and core purpose of a strict, exclusive state neutrality principle.

\section{Concluding remarks}

The above analysis and reflections intended to show that the CJEU rulings in Achbita and Bougnaoui do not provide clear guidance for the member states on how to deal with the issue of wearing religious clothing or symbols in employment. In fact, they are extremely brief, minimally motivated and ambiguous. An explanation for this could well be that the Court itself was seriously divided internally on the proper interpretation of the applicable EU law, just as the advocates general who advised the Court in those cases. Where the judgments allow for different interpretations, from the perspective of the fundamental rights of workers the better one would be the interpretation which provides them with more protection of their religious freedom. At the same time, considerations of respecting diversity would seem to call for allowing the member states more leeway to regulate the issue at stake where other important values and interests are involved, such as constitutionally embedded, specific conceptions of state neutrality. As the latter does not seem to be at issue in the private sector this would suggest that where a private employment relationship is concerned the Court should give priority to the freedom of religion of workers by developing strict and more uniform standards. The UK and the Netherlands provide good examples. This would tie in with the fact that regarding private employment approaches in the member states diverge much less than those regarding the public sector. Anyway, given their terseness and ambiguity, the 
rulings seem to leave the Court with ample room for developing its case law in various directions. We will have to wait and see how things will turn out. 